\title{
Seed germination and triterpenoid content of Anemopaegma arvense (Vell.) Stellfeld varieties
}

\author{
Ana M. S. Pereira · Antonieta N. Salomão - Ana H. Januario · \\ Bianca W. Bertoni · Saulo F. Amui · Suzelei C. França · \\ Antonio L. Cerdeira · Rita M. Moraes
}

Received: 30 September 2005/ Accepted: 13 April 2006/Published online: 7 December 2006

(C) Springer Science+Business Media B.V. 2006

\begin{abstract}
Anemopaegma arvense (Vell.) Stellfeld, Bignoniaceae, is a native species of the Brazilian savanna (Cerrado) and is commonly known as catuaba among the local farmers. Seeds of three varieties were collected in different localities and submitted to germination and storage studies in attempting to domesticate this species as a medicinal crop for small farmers located in Brazilian Cerrado. Germination tests revealed that catuaba seeds presented a dormancy period of 6 weeks, and $63 \%$ of the seedlings have emerged after 12 weeks of the planting
\end{abstract}

A. M. S. Pereira · A. H. Januario - B. W. Bertoni · S. F. Amui · S. C. França

Plant Biotechnology Center, University of Ribeirao Preto, Av. Costabile Romano, 2201, Ribeirao Preto, SP 14.096-380, Brazil
A. N. Salomão
Brazilian Department of Agriculture, Agricultural Research Service, Embrapa-Cenargen, C.P. 02372, Brasilia, DF 70770-900, Brazil

\author{
A. L. Cerdeira \\ Brazilian Department of Agriculture, Agricultural \\ Research Service, Embrapa-Environment, C.P. 69, \\ Jaguariuna, SP 13820-000, Brazil \\ R. M. Moraes $(\square)$ \\ National Center for Natural Products Research, \\ Research Institute of Pharmaceutical Sciences, School \\ of Pharmacy, The University of Mississippi, \\ University, MS 38655, USA \\ e-mail: rmoraes@olemiss.edu
}

time. Storing catuaba seeds at low temperatures $\left(-20\right.$ and $\left.-196^{\circ} \mathrm{C}\right)$ has not affected emergence and survival. These findings suggested that $A$. arvense seeds have an orthodox behavior resisting well to dehydration and low temperature storage. Three catuaba varieties were characterized morphologically and chemically. The presence of triterpenes such as oleanolic acid and betulinic acid were identified and quantified in these varieties. Previous report has shown that these compounds have promising anticancer activities and herein the results point that the aerial parts yielded more triterpenes than the roots. The combination of higher capacity and preferential accumulation of triterpenes in the aerial parts of catuaba makes this plant a potential candidate for agricultural production or in situ sustainable harvests as a promising alternative to the destructive collection of the natural population.

Keywords Anemopaegma arvense .

Bignoneaceae $\cdot$ Catuaba $\cdot$ Medicinal plant .

Oleanolic acid $\cdot$ Seed germination · Triterpenes

\section{Introduction}

Catuaba, Anemopaegma arvense (Vell.) Stellfeld, Bignoniaceae, is a native species of the Brazilian savanna (Cerrado). Cosmetic products containing catuaba extracts were patented as being 
anti-wrinkle, preventing skin aging, stimulating hair growth and blocking sunscreen (Kokou et al. 2000; Shimizu 2001; Yamashita and Fujita 2002; Mio et al. 2003). Among local people catuaba has also been used as a stimulant, aphrodisiac, and for the treatment of hypertension (Hamet 1937). Phytochemical study revealed that catuaba extracts contain catechin and cinchonains (Uchino et al. 2004).

To supply the demand for roots, the commercial part of catuaba, the Cerrado's natural resources are being depleted. Greater damage than overexploitation is the relentless destruction of its habitat since the area has become the new agricultural frontier in Brazil for sowing cash crops such as soybean and corn in Brazil (Myers et al. 2000). Recent surveys show that this ecosystem is a rich biome with 7,000 plant species but just a few of them have been investigated regarding physiology, growth and development behavior, propagation and sustainability (Melo and Eira 1995; Gemaque et al. 2002; Botezelli et al. 2000).

Although, the cosmetic industry has claimed therapeutic properties of $A$. arvense, cultivation still needs to be further encouraged. Thus it was included into a conservation research program funded by the Biodiversity Research Program of Sao Paulo, Brazil (BIOTA). The major effort of this research program is to preserve the gene pool of therapeutically relevant plant species. Pereira et al. (2003) reported an in vitro propagation and conservation protocols to preserve catuaba elite biotypes. In order to understand the gene pool variability of the species, the present study was conducted to characterize morphologically and chemically the three varieties found in their native habitats and to study seed germination behavior of this species.

\section{Materials and methods}

Catuaba seeds were collected during the year of 2002 in three regions in Brazil, in Uberlandia County, Minas Gerais state (Lat. $26^{\circ} 04^{\prime} 21 ; 00^{\prime \prime} \mathrm{N}$, Long. $48^{\circ} 08^{\prime} 58 ; 00^{\prime \prime} \mathrm{W}$, Alt. $747 \mathrm{~m}$ ), in Rio Verde County, Goias state (Lat. $18^{\circ} 08^{\prime} 43 ; 30^{\prime \prime} \mathrm{N}$, Long. 49 57'26;90”W, Alt. $523 \mathrm{~m}$ ) and in Pedregulho County, Sao Paulo state (Lat. $20^{\circ} 28^{\prime} 20^{\prime \prime}$ N, Long.
47²4'39;00”'W, Alt. 1,017 m). Specimens collected in each location were pressed and deposited at the herbarium of the Biotechnology Department, Ribeirao Preto University with the following voucher numbers HPM-UNAERP 028, HPM-UNAERP 093 and HPM-UNAERP 0750.

Twigs of these three accessions were collected for morphological and chemical characterization. Per accession 25 measurements were made for the various characters. Based on the morphological characters the accessions were identified as different varieties; Anemopaegma arvense var. petiolata Bur., Anemopaegma arvense var. puberula P.DC. and Anemopaegma arvense var. glabra P.DC.

\section{Germination studies}

One week after seeds were collected, they were submitted to germination studies using sand as substrate. Seeds were sown into planting trays at depths of $1 \mathrm{~cm}$ in three replicates of 100 seeds with Plantimax ${ }^{\circledR}$ substrate composed of the mixture 2:1:1:1 v/v (manure, vegetable coal, soil, and sand) and kept in a glasshouse at $75 \%$ relative humidity, temperature at $30 \pm 3^{\circ} \mathrm{C}$ and daily mist irrigation for $30 \mathrm{~min}$. Germination was evaluated weekly during 3 months. When cotyledons have emerged, seeds were counted as germinated. Root length was measured at the end of the experiment. Seeds of each variety were considered as a treatment and 100 seeds were used per replication of a treatment. Treatments were replicated three times (Table 2). Data were submitted to Tukey test $(P \leq 0.05)$.

For studying seed storage behavior the seeds were dehydrated to $5.5 \%$ moisture content in an air forced dryer and then exposed to temperatures of -20 and $-196^{\circ} \mathrm{C}$ (liquid nitrogen) for 6 months. This procedure was repeated four times using 20 seeds per replication. After the storage of low temperature seeds were placed on wet paper towel and kept in the dark at $25^{\circ} \mathrm{C}$ for germination. Data were analyzed by Tukey test $(P \leq 0.05)$. Glasshouse germination studies were conducted at $30^{\circ} \mathrm{C}$ and germination after storage at $25^{\circ} \mathrm{C}$ because preliminary studies have shown that this was the best range for germination and the extreme temperatures were chosen. 
Growth measurements and yield of triterpenes

Seeds were sowed in plastic containers (10 1), 50 seeds with three replications, containing soil/sand substrate at 1:1 ratio. These containers were kept in the greenhouse at average temperature of $30^{\circ} \mathrm{C}$ and daily irrigation for $30 \mathrm{~min}$. Growth measurements from soil surface up to the apical meristem were taken from aerial and underground parts at 5, 8 and 30 months after the seeds emerged.

Plants were harvested and dried at $50^{\circ} \mathrm{C}$, roots and aerial parts were ground separately into a fine powder using coffee grinder. Ground plant material $(100 \mathrm{mg})$ was extracted with methanol by maceration for $30 \mathrm{~min}$ under sonication. The solvent was evaporated to dryness and the residue dissolved in methanol. Each sample was extracted in triplicates. Extracts were analyzed by HPLC analysis performed by Shimadzu LC-10AD VP, Column LC-18 Shim-pack $25 \mathrm{~cm} \times 4.6 \mathrm{~mm}$ $(5 \mu \mathrm{m})$; mobile phase $\mathrm{MeOH} 85 \%$ and $15 \%$ $\left(\mathrm{H}_{2} \mathrm{O}+0.1 \% \mathrm{CH}_{3} \mathrm{COOH}\right)$ for $15 \mathrm{~min}, \mathrm{MeOH}$ $100 \%$ (5 min) at $0.9 \mathrm{ml} / \mathrm{min}$. Absorbance was measured at $210 \mathrm{~nm}$ according to the procedure described by Bolta et al. (2000). The pentacyclic triterpenoid standards oleanolic acid, betuline and betulinic acid and ursolic acid were purchased from Sigma.

\section{HPLC-mass spectrometry analysis}

Low-resolution ESI analyses were performed on a triple quadrupole mass spectrometer (QuattroLC, Micromass, Manchester, UK). Samples were injected with a syringe pump at flow rate of $10 \mu \mathrm{l}$ per min., voltage was maintained at $3 \mathrm{kV}$, for ion extraction the applied cone energy was $20 \mathrm{~V}$. Mass spectrometry data were acquired in the negative mode for acid compounds while for betulin the mode was positive.

\section{Results and discussion}

Aerial part distinct morphologic characters of the three $A$. arvense varieties collected in different localities are detailed in Table 1, Fig. 1. Plants of petiolata variety are hairless, taller with broader leaves (Ferrreira 1973). Presence of hair in the stem and leaves are well noticed in puberula variety, while glabra has no hair. Plants of both varieties puberula and glabra are the same height but shorter than petiolata.

Seeds of the Bignoniaceae are distinguished from related families due to the absence of endosperm; fruits often show conspicuously wings, which are commonly perceived as winged seeds (Laurence 1963). In evaluating the growth and development of the catuaba seedlings, data revealed that the presence of wings is not critical for emergence. In fact, seedlings of winged seeds produced shorter roots than non-winged ones (data not shown). Thus, wing removal of the seeds might be a helpful practice to obtain well-rooted plants. In addition, the results in Table 2 revealed that after sowing, seeds of catuaba were dormant for 42 days. After this period, seeds started to emerge and most sprouted in the period up to day 84 after planting. The speed of germination varied among the three varieties. Cotyledons of puberula and petiolata were noticed 28 days after planting while glabra seedlings required 12 days. At 49 weeks after planting, (84 days), germination percentage among these catuaba varieties (Table 2) was alike, but roots were more developed in seedlings of variety petiolata.

Seed technologists have classified seeds into orthodox, intermediate and recalcitrant species depending on their storage behavior after dehydration (Kermode 1990). Seeds that tolerate dehydration are classified as orthodox, while intermediates survive dehydration down to $10 \%$ not lower. Recalcitrant seeds are sensible to dehydration. Catuaba seeds survived dehydration to $5.5 \%$ moisture content and freezing temperatures between -20 and $-196^{\circ} \mathrm{C}$ for 6 months with $84 \%$ of germination for both temperatures. According to Kermode's (1990) seed classification, this result suggests that catuaba seeds have orthodox seed storage behavior.

The presence of oleanoic acid, ursolic acid, betulinic acid and betuline in catuaba extracts of aerial and root parts was identified by HPLC/UV peaks $\left(t_{\mathrm{R}}=15.871 ; 16.427 ; 17.180 \mathrm{~min}\right.$, respectively). MS/MS spectral analysis was conducted to identify these triterpene compounds. They were clearly confirmed after comparison of their 
Table 1 Macroscopic examination of morphological characters of catuaba varieties

\begin{tabular}{llll}
\hline Characters & \multicolumn{2}{l}{ Varieties } & \\
\cline { 2 - 4 } & petiolata & puberula & glabra \\
\hline Hair on the stem & No & Yes & No \\
Pilose leaf & No & Yes & No \\
Rugged leaf & No & Yes & No \\
Leaf length $(\mathrm{cm})$ & $11.0 \mathrm{a}$ & $5.0 \mathrm{~b}$ & $7.8 \mathrm{~b}$ \\
Leaf width $(\mathrm{cm})$ & $1.0 \mathrm{a}$ & $0.2 \mathrm{c}$ & $0.7 \mathrm{~b}$ \\
Plant height $(\mathrm{cm})$ & $75.0 \mathrm{a}$ & $31.0 \mathrm{~b}$ & $34.3 \mathrm{~b}$ \\
\hline
\end{tabular}

Size values are means of 25 individual measurements.

Means followed by the same letter in the row do not differ significantly according to Tukey test (0.05)

pseudo-molecular ino peaks betulin $[\mathrm{M}+\mathrm{H}]^{+}$ 443, betulinic acid $[\mathrm{M}-\mathrm{H}]^{+} 455$ and oleanolic acid $[\mathrm{M}-\mathrm{H}]^{+} 455$ and fragmentation patterns with those of standards. Oleanolic acid, the major constituent, was also isolated as a pure substance from catuaba $\mathrm{CHCl}_{3}$ extract and its structured confirmed by NMR data.

These triterpenoids isolated from catuaba extracts in preclinical studies have shown promising antitumor activity (Mahato and Kundu 1994;
Tokuda et al. 1986; Fulda and Debatin 2000; Lee et al. 2002; Zuco et al. 2002; Urech et al. 2005). Roots are the sole biomass with commercial value. Our data, (Table 3) however, reveal that aerial parts yielded 10 times more triterpenes than the roots. Catuaba is a slow growing species. A significant and practical conclusion derived from this work is the high harvest potential of aerial parts for triterpene production; while sustainability of the species is assured by leaf tissues as renewable sources (Table 3). Zschocke et al. 2000, proposed the concept of plant part substitution to supply the demand for active constituents while preserving the most threatened South African medicinal plants such as Eucomis autumnalis (Mill.) Chitt. (bulb), Siphonochilus aethiopicus J.M. Wood et Franks (rhizome), Ocotea bullata (Burchell) Baillon (bark), and Warburgia salutaris (Bertol.f.) Chiov. (bark). For continuous supply of the demand, leaf tissue would become the source of the active constituents to substitute destructive harvest of non-renewable source. Our data on $A$. arvense corroborate with Zschocke et al. (2000) concept
Fig. 1 Voucher specimens of the three varieties of catuaba collected in the states of Goias, Minas Gerais, and Sao Paulo, Brazil
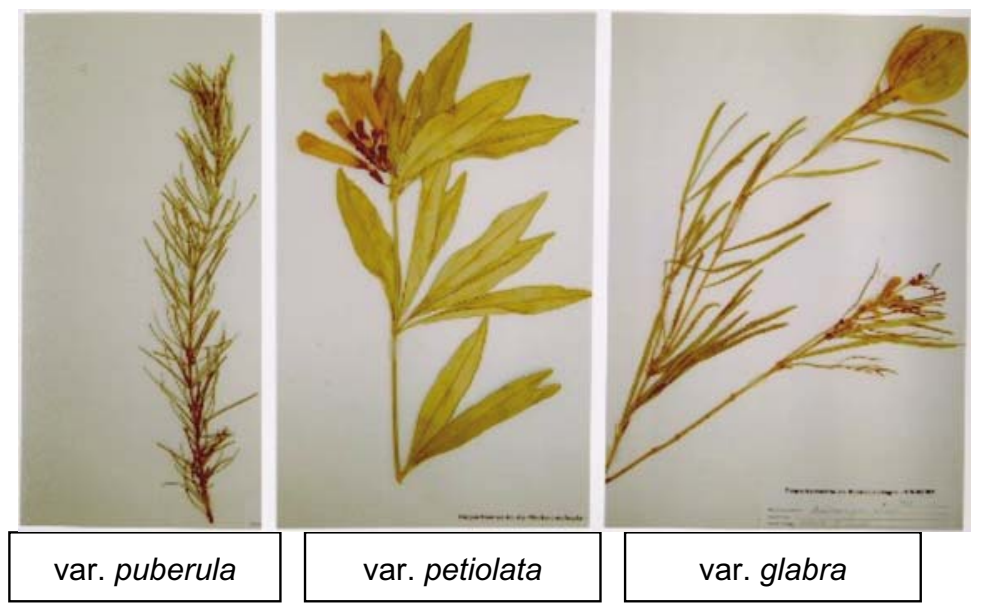

Table 2 Seed germination and root length $(\mathrm{cm})$ of catuaba seedlings

\begin{tabular}{lllllllr}
\hline Varieties & \multicolumn{2}{l}{ Germination (\%) } & \multicolumn{2}{c}{ Root length (cm) } \\
\cline { 2 - 7 } & $28 \mathrm{DAP}^{\mathrm{a}}$ & $35 \mathrm{DAP}$ & $42 \mathrm{DAP}$ & $49 \mathrm{DAP}$ & $56 \mathrm{DAP}$ & 84 DAP \\
\hline puberula & $3.3 \mathrm{a}$ & $23 \mathrm{a}$ & $53 \mathrm{a}$ & $63 \mathrm{a}$ & $70 \mathrm{a}$ & $70 \mathrm{a}$ & $6.4 \mathrm{~b}$ \\
petiolata & $3.3 \mathrm{a}$ & $27 \mathrm{a}$ & $47 \mathrm{a}$ & $50 \mathrm{a}$ & $50 \mathrm{~b}$ & $63 \mathrm{a}$ & $12.3 \mathrm{a}$ \\
glabra & $0.0 \mathrm{~b}$ & $0.0 \mathrm{~b}$ & $0.0 \mathrm{~b}$ & $20 \mathrm{~b}$ & $20 \mathrm{c}$ & $58 \mathrm{ab}$ & $6.5 \mathrm{~b}$
\end{tabular}

${ }^{a}$ DAP = Days after planting. Means followed by the same letter within the column did not differ significantly according to Tukey test $(0.05)$ 
Table 3 Triterpene content ( $\mu \mathrm{g} / \mathrm{g}$ dry weight $\times 10^{-2}$ ) found in catuaba varieties puberula, petiolata and glabra

\begin{tabular}{lcrcr}
\hline Sample & Betuline & $\begin{array}{l}\text { Betulinic } \\
\text { acid }\end{array}$ & $\begin{array}{l}\text { Oleanolic } \\
\text { acid }\end{array}$ & $\begin{array}{l}\text { Ursolic } \\
\text { acid }\end{array}$ \\
\hline $\begin{array}{l}\text { Roots } \\
\text { puberula }\end{array}$ & $5.0 \mathrm{a}$ & $13.0 \mathrm{a}$ & $42.1 \mathrm{~b}$ & $0.0 \mathrm{~b}$ \\
petiolata & $6.0 \mathrm{a}$ & $10.0 \mathrm{a}$ & $78.0 \mathrm{a}$ & $9.0 \mathrm{a}$ \\
glabra & $0.0 \mathrm{~b}$ & $0.0 \mathrm{~b}$ & $4.0 \mathrm{c}$ & $0.0 \mathrm{~b}$ \\
$\begin{array}{l}\text { Leaves } \\
\text { puberula }\end{array}$ & $99.0 \mathrm{a}$ & $177.0 \mathrm{a}$ & $565.0 \mathrm{a}$ & $0.0 \mathrm{c}$ \\
petiolata & $66.0 \mathrm{~b}$ & $55.0 \mathrm{~b}$ & $203.0 \mathrm{~b}$ & $28.0 \mathrm{~b}$ \\
glabra & $87.0 \mathrm{a}$ & $73.0 \mathrm{~b}$ & $289.0 \mathrm{~b}$ & $77.0 \mathrm{a}$ \\
\hline
\end{tabular}

Statistical comparisons were done among varieties within the plant part. Means followed by the same letter within column do not differ significantly according to Tukey test (0.05)

of plant part source change, and strongly suggest that the proposed strategy could become a valuable solution for medicinal species found in hot spot area such as the Brazilian Cerrado.

The presence of polyembryonic seedlings was noticed at a frequency of $10 \%$ among the catuaba varieties. Polyembryonic seedlings have been well studied in citrus and mangos with great impact in their breeding program (Koltunow et al. 1996; Shnell 1994). More study is required to determine the type of apomixis in catuaba and its potential impact in plant production.

In conclusion, this study can be summarized as follows (1) catuaba seeds show initial dormancy during 6 weeks after sowing, (2) they belong to the orthodox seed storage type, (3) plants contain higher amounts of biological active triterpenes in the aerial parts than in the roots, and (4) polyembryony was noticed.

Acknowledgement Research funded by FAPESP, The State of Sao Paulo Research Foundation, Brazil. Project Number (Projeto tematico-Biota 99/10610).

\section{References}

Bolta Z, Baricevic D, Bohanec B, Andrensek S (2000) A preliminary investigation of ursolic acid in cell suspension culture of Salvia officinalis. Plant Cell Tiss Org Cult 62:57-63

Botezelli L, Davide AC, Malavasi MM (2000) Características dos frutos e sementes de quatro procedência de Dipteryx alata Vogel (Baru). Cerne 6(1):9-18
Ferreira MB (1973) Bignoneaceae do Distrito Federal - O genero Anemopaegma Mart. Oreades 6:28-39

Fulda S, Debatin KM (2000) Betulinic acid induces apoptosis through a direct effect on mitochondria in neuroectodermal tumors. Med Pediat Oncol 35:616618

Gemaque RCR, Davide AC, Faria JMR (2002) Indicadores de maturidade fisiológica de sementes de ipêroxo (Tabebuia impetiginosa (Mart.) Standl.). Cerne $8(2): 87-94$

Hamet R (1937) Su quelques effets physiologiques de la drogue brésilienne connue sous le nom de "folhas de catuaba". Com Rendus Soc Biol 124:904-907

Kermode AR (1990) Regulatory mechanisms involved in the transition from seed development to germination. Critic Rev Plant Sci 9:155-195

Kokou Y, Akio M, Shoji N, Koho KT (2000) Skin external use agent. JP-patent Number 2000143482. May 23

Koltunow AM, Hidata T, Robinson SP (1996) Polyembryony in citrus. Accumulation of seed storage proteins in seeds and in embryos cultured in vitro. Plant Phys 110(2):599-609

Laurence GHM (1963) Taxonomy of vascular plants. The McCmillan Co, New York, NY

Lee I, Lee YH, Leonard J (2002) Ursolic acid induced changes in tumor growth $\mathrm{O}_{2}$ consumption and tumor interstitial fluid pressure. Anticancer Res 21:28272834

Mahato S, Kundu AP (1994) ${ }^{13}$ C NMR spectra of pentacyclic triterpenoids - a compilation and some salient features. Phytochem 37(6):1517-1575

Mello CMC, Eira MTS (1995) Conservação de sementes de jacaranda mimosos (Jacaranda acutifolia Humb. \& Bonpl.-Bignoniaceae). Rev Bras Sem 17(2):193-196

Mio K, Inoue A, Yokoyama D, Atsushi N, Ishimaru H, Midorikawa T (2003) Oral hair growth stimulants containing odd-numbered fatty acids, or alcohols, plant or algae extracts, and/or tocotrienol and foods containing them. JP-patent 2003160486. June 3

Myers N, Mittermeier RA, Mittermeier CG, Fonseca GAB, Kent J (2000) Biodiversity hotspots for conservation priorities. Nat 403:853-858

Pereira AMS, Amui SF, Bertoni BW, Moraes RM, França SC (2003) Micropropagation of Anemopaegma arvense: conservation of an endangered medicinal plant. Planta Med 69:571-573

Shimizu H (2001) Antioxidant containing plant extracts for cosmetics and pharmaceuticals. JP-patent 20011139417. May 22

Shnell RJ (1994) Eliminating zygotic seedlings in Turpentine mango rootstock population by visual rouging. HortSci 29(4):319-320

Tokuda H, Ohigashi H, Kopshimizu K, Ito K (1986) Inhibitory effects of ursolic and oleanolic acid on skin tumor promotion by 12-O-tetradecabiykogirbik-13acetate. Cancer Let 33:279-285

Uchino T, Kawahara N, Sekita S, Satake M, Saito Y, Tokunaga H, Ando M (2004) Potent protecting effects of Catuaba (Anemopaegma mirandum) extracts against hydroperoxide-induced cytotoxicity. Toxicol In Vitro 18:255-263 
Urech K, Scher JM, Hostanska K, Becker H (2005) Apoptosis inducing activity of viscin a lipophyllic extract from Viscum album L. J Pharm Pharmacol 57:101-109

Yamashita M, Fujita S (2002) Cosmetics containing sunscreen agents and plant extracts. PR-patent 2002308750. Oct. 23
Zschocke S, Rabe T, Taylor JLS, Jäger Ak, van Staden J (2000) Plant part substitution - a way to conserve endangered medicinal plants? J Ethnopharm 71:281-291

Zuco V, Supino R, Righetti SC, Cleris L, Marchesi E, Gambacorti-Passerini C, Formelli F (2002) Selective cytotoxicity of betulinic acid on tumor cell lines but not on normal cells. Cancer Let 175:17-25 